\title{
Spatial and temporal distribution of species diversity in semideciduous seasonal forests with occurrence of fire
}

\author{
Kmila Gomes da Silva ${ }^{1 *}$, Nelson Venturin ${ }^{1}$, Warley Augusto Caldas Carvalho ${ }^{1}$, \\ Anderson Pedro Bernardina Batista ${ }^{1} \&$ Leônidas Leoni Belan ${ }^{2}$ \\ 1. Universidade Federal de Lavras, Departamento de Engenharia Florestal, Câmpus Universitário, 37200-000, Lavras, \\ MG, Brazil; kmila22@yahoo.com.br, venturin@dae.ufla.br,warleycaldas@dcf.ufla.br, \\ anderson_pedro22@yahoo.com.br \\ 2. Universidade Federal de Lavras, Departamento de Fitopatologia, Câmpus Universitário, 37200-000, Lavras, MG, \\ Brazil; leonidas_agronomia@yahoo.com.br \\ * Correspondence
}

Received 21-III-2016. Corrected 25-I-2017. Accepted 27-II-2017.

\begin{abstract}
The spatial and temporal distributions of vegetation can be influenced by edaphic and environmental factors as well as disturbances. The present study was undertaken to characterize the distribution and spatial dependence of species diversity in a fragment of semideciduous seasonal forest after a disturbance event by fire and to identify changes during natural regeneration. The fire, occurred in 1999, and surveys were undertaken in 2000, 2005 and 2014 in 26 geo-referenced plots $\left(400 \mathrm{~m}^{2}\right)$ distributed along two transects. The Fire Damage Index (FDI) in each plot was based on a scale from 0 to 5 , and all of the arboreal individuals with diameters at breast height $(\mathrm{DBH}) \geq 5 \mathrm{~cm}$ were identified in each plot. Species diversity was calculated using the Shannon index (H'), and species richness (S) was estimated using species accumulation curves; variations between the surveys compared based on the means and standard errors. The S, H' and FDI data were submitted to non-spatial exploratory and geostatistical analyses. After adjusting the semivariograms, the levels of spatial dependence were classified, and interpolation of the variables values were performed using ordinary kriging to characterize their spatial distributions in the form of maps. Spatial analysis was used to identify and characterize differences between the post-fire surveys in terms of the configurations of the arboreal community. The fire event influenced the spatial and temporal structures of the variables $\mathrm{S}$ and $\mathrm{H}^{\prime}$. These variables showed spatial dependence and aggregated distributions, with reduction in the distance under spatial influences and a uniformity of individuals distribution in the forest fragment at the different surveys. This research characterized the distribution and spatial dependence of the variables $\mathrm{S}$ and $\mathrm{H}^{\prime}$ in a forest fragment after a fire event and the alterations in the arboreal community structure during natural regeneration. Rev. Biol. Trop. 65 (2): 525-534. Epub 2017 June 01.
\end{abstract}

Key words: Atlantic Forest, Brazil, forest fragmentation, anthropogenic disturbance, long-duration study, spatial dependence, geostatistics.

Forest fragmentation is one of the principal factors promoting forest degradation. In addition to generating forest mosaics at different regeneration stages, fragmentation favors the propagation of subsequent fires and other environmental disturbances that promote spatial discontinuity of forest composition (Amaral, Ferreira, Watzlawick, Longhi, \& Sebem, 2013b). In the Atlantic Forest biome, for example, habitat degradation results in reductions of both forest cover and species diversity (Ribeiro, Martensen, Metzer, Tabarelli, Scarano, \& Fortin, 2011) with serious implications for forest ecosystem functioning and organization (Silva-Matos, Fonseca, \& Silva-Lima, 2005; Lima \& Moura, 2008; Pereira, Filho, Eisenlohr, Miranda, \& Filho, 2015). The spatial distribution of forest species is an interactive 
phenomenon involving competition, tree architecture, and the occurrence and availability of forest openings (Sanquetta, Corte, Salzmann, \& Vulcanis, 2007; Rode, Filho, Machado, \& Galvão, 2010), and disturbances will be reflected in the spatial dependence of forest variables (Dormann, 2007; Miller, Franklin, \& Aspinall, 2007).

Studies of the uncertain, ambiguous, and nonlinear natures of forest community disturbances will require the use of statistical tools capable of measuring those interactions to be able to increase the efficiency of remediation strategies. Geostatistics can be used to represent the spatial distributions of environmental factors and examine the ecological aspects of recovery and these tools have been used by numerous researchers to examine the spatial dependence of forest components (Rufino, Thiersch, Ferreira, Kanegae-Junior, \& Fais, 2006; Amaral, Ferreira, Watzlawick, \& Genú, 2010; Neves, Lemos, Gonzáles, Vieira, \& Siqueira, 2010; Amaral, Ferreira, Lisboa, Longhi, \& Watzlawick, 2013a). These studies can help generate a better understanding of the establishment and reproduction of individuals (Condit et al., 2000), the maintenance of species diversity, succession, evolution, and adaptations (Legendre \& Fortin, 1989), and optimize techniques for sustainable forest management, and sampling and monitoring of plant species (Pereira, Péllico-Netto, \& Carvalho, 2006). Spatial distribution studies require long-term monitoring of the ecological aspects of forest communities and must accompany recuperation processes and their rates long after a disturbance event (Taylor, Hamilton, Lewis, \& Nantle, 2008).

Thus, this study was developed to characterize the distribution and spatial dependence of species richness and diversity in a forest fragment, after a disturbance event by fire, and to identify alterations in the arboreal community structure during natural regeneration.

\section{MATERIAL AND METHODS}

Study area: The present study was conducted in a remnant of seasonal semideciduous montane forest (Instituto Brasileiro de Geografia e Estatística, 2012), in the municipality of Ibituruna, Minas Gerais State, Brazil $\left(21^{\circ} 09^{\prime} 40^{\prime} \mathrm{S}-44^{\circ} 50^{\prime} 10^{\prime} \mathrm{W}\right)$. The fragment covers an area of 57.06 ha in a mountainous region, with hillside inclinations between $25^{\circ}$ and $40^{\circ}$. The regional climate is humid in the Austral summer and dry in winter (Cwb by the Köppen classification), with an annual mean temperature of $20.4{ }^{\circ} \mathrm{C}$ and an annual mean rainfall of $1460 \mathrm{~mm}$ (Dantas, Carvalho, \& Ferreira, 2007). The soils are predominantly litholic neosols, haplic cambisols, and red argisols (Empresa Brasileira de Pesquisa Agropecuária, 2006). The forest remnant studied was surrounded by pastureland, coffee plantations, fragments of native vegetation, and a lake formed by a hydroelectric dam. A forest fire occurred in the area in August/1999, affecting an irregularly shaped area in a West to East path through the fragment (Silva, Filho, Venturin, Carvalho, \& Gomes, 2005).

\section{Delimitation of the plots and evalua-} tions: In January 2000, twenty-six $400 \mathrm{~m}^{2}$ plots $(20 \times 20 \mathrm{~m})$ were established along two transects parallel to the Western and Eastern borders of the fragment to represent the environmental variability extant in the areas impacted by fire. The plots were arranged approximately $30 \mathrm{~m}$ one from the other along each transect. All of the plots were geo-referenced.

Floristic surveys were undertaken in 2000, 2005 and 2014 by marking, recording, and identifying all individuals with diameters at breast height $(\mathrm{DBH}) \geq 5 \mathrm{~cm}$ in each plot, and then calculating their Shannon diversity indices (H') (Magurran, 1988) and species richness (S).

The species accumulation curves were plotted and the variations between the different surveys compared, based on their means 
and standard errors. Comparisons between the curves were based on the $95 \%$ confidence interval (Zar, 2010) using EstimateS version 9.1 software (Cowell, 2013).

The Fire Damage Index (FDI) was calculated based on the scale proposed by Nascimento et al. (2000), with evaluations varying from zero (absence of fire in the plot) to five (maximum fire intensity) for each plot.

Geostatistical analyses: The S, H' and FDI values were used in the geostatistical analyses in association with the central coordinates of each plot. The data were initially submitted to non-spatial exploratory analyses to calculate the mean, maximum and minimum values, the coefficients of variation, and standard deviations. Based on these exploratory analyses, geostatistical analyses were undertaken to characterize the dependence and spatial variations of the variables. To analyze the structure of their spatial dependence, variographic analyses were made of the S, H' and FDI data. The experimental semivariograms were adjusted to the exponential and spherical models (Journel \& Huijbregts, 1978) using the ordinary least square method. The adjusted models were used to estimate the nugget effect $\left(\mathrm{C}_{0}\right)$, sill $\left(\mathrm{C}_{0}+\mathrm{C}\right)$, and range $(\mathrm{A})$ parameters, which were used, in turn, to calculate the degree of spatial dependence (SD) using the equation: $\left[\mathrm{C} /\left(\mathrm{C}_{0}+\mathrm{C}\right)\right] \times 100$. Spatial dependence was classified following Biondi, Myers and Avery (1994) with SD considered as weak if $\leq 35.0 \%$, moderate if $>35.0 \%$ and $\leq 75.0 \%$, and strong if $>75.0 \%$.

After adjusting the semivariograms, the data were interpolated by ordinary kriging to characterize, in the form of maps, the spatial dependence structures of the variables in each survey. The R computational system was used for the statistical and geostatistical analyses and for the plotting of maps (R Development Core Team, 2012) using the geoR packages (Diggle \& Ribeiro-Junior, 2007) and ArcGis, version 10.1, with the Geostatistical Analyst extension (Environmental Systems Research Institute, 2010).

\section{RESULTS}

Species richness and diversity: No differences were found between the different surveys, based on the accumulation curves of $\mathrm{S}$ and $\mathrm{H}$ ' variables. Some increases in those variables, proportional to species abundances, were observed, although the curves of these variables for all surveys (2000, 2005 and 2014), showed the same patterns and did not differ among themselves (Fig. 1).

After the fire, the number of individuals and species detected was similar: 1046 individuals were catalogued in the year 2000, 979 in 2005, and 1093 in 2014; these represented 159,
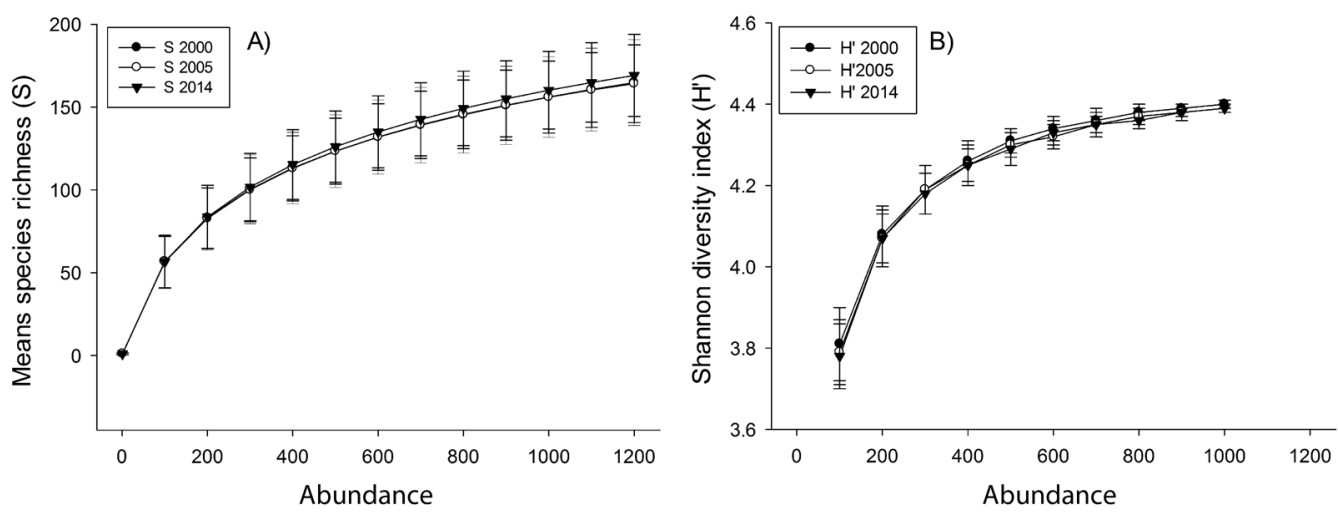

Fig. 1. Species accumulation curves as a function of abundance in a semideciduous seasonal forest in Ibituruna, MG, Brazil, in 2000, 2005 and 2014. A. Mean species richness and B. Shannon Diversity Index. 
TABLE 1

Statistical summary of the species richness (S) and Shannon diversity index (H') variables in three floristic surveys undertaken in a fragment of semideciduous seasonal forest in Ibituruna, MG, Brazil

\begin{tabular}{ccccccccc} 
Variable & Survey Year & Average & V. máx. ${ }^{1}$ & V. mín. & $\mathrm{s}^{2}$ & s & CV \\
S & 2000 & 23.88 & 36 & 6 & 49.42 & 7.03 & 29.42 \\
& 2005 & 22.42 & 33 & 8 & 42.25 & 6.50 & 28.99 \\
& 2014 & 23.31 & 31 & 11 & 28.41 & 5.33 & 22.89 \\
H' & 2000 & 2.86 & 3.41 & 1.53 & 0.17 & 0.41 & 14.36 \\
& 2005 & 2.80 & 3.32 & 1.81 & 0.14 & 0.38 & 13.71 \\
& 2014 & 2.86 & 3.32 & 2.22 & 0.08 & 0.29 & 9.98 \\
FDI & 1999 & 2.19 & 4 & 0 & 1.69 & 1.30 & 59.15 \\
\hline
\end{tabular}

${ }^{1}$ V. Max. = Maximum value; V. Mín. $=$ Minimum value; $\mathrm{s}^{2}=$ Variance; $\mathrm{s}=$ Standard Error; $\mathrm{CV}=\mathrm{Coefficient}$ of variation.

154, and 163 species, respectively. The most abundant species in all three forest surveys were Cupania vernalis, Gymnanthes klotzschiana, and Prunus myrtifolia; but only C. vernalis and G. klotzschiana were among the ten species with the highest densities in both transects. The $\mathrm{H}^{\prime}$ values for the three surveys were 4.41, 4.39, and 4.40 nats.ind. ${ }^{-1}$ respectively, indicating that there were no statistical differences between them, and making it impossible to characterize the influence of fire on plant diversity, based on the species accumulation curves for the evaluated years after the fire event.

Spatial continuity analyses: Based on the descriptive analyses of S and H' data, there were alterations of those variables after the fire event and heterogeneity of the data, with higher values in the year 2000 variance $\left(\mathrm{s}^{2}\right)$, standard error (s), and coefficient of variance (CV). The median values of the variables did not oscillate during the surveys, although there were variations in data amplitudes, with the largest values observed in 2000 and the smallest in 2014 (Table 1), characterizing a de-structuring of the variables as a possible consequence of fire, with posterior stability. The reductions of the variance $\left(\mathrm{s}^{2}\right)$, and coefficient of variance (CV) values of the $\mathrm{S}$ and $\mathrm{H}^{\prime}$ values between the 2000 and 2014 surveys (Table 1), confirm this observation.

Spatial analyses demonstrated alterations in the structural variables following the fire. There was spatial dependence of $\mathrm{S}$ and $\mathrm{H}^{\prime}$ variables and the spherical and exponential models were adjusted accordingly (Fig. 2; Table 2). The $\mathrm{S}$ variable spatial dependence resulted moderate in all three surveys; while $\mathrm{H}^{\prime}$

TABLE 2

Parameters of semivariograms models referring to the species richness (S), Shannon diversity index (H') and Fire Damage Index (FDI) in a fragment of semideciduous seasonal forest in Ibituruna, M G, Brazil, during plant surveys undertaken in 2000, 2005 and 2014

\begin{tabular}{|c|c|c|c|c|c|c|}
\hline Variable & Models & Survey Year & $\mathrm{Co}^{1}$ & $(\mathrm{Co}+\mathrm{C})$ & $\mathrm{A}(\mathrm{m})$ & SD $(\%)$ \\
\hline \multirow[t]{3}{*}{ S } & Spherical & 2000 & 17 & 44.82 & 221.90 & 62 \\
\hline & & 2005 & 16 & 38.86 & 185.43 & 59 \\
\hline & & 2014 & 10 & 28.25 & 132.54 & 65 \\
\hline \multirow[t]{3}{*}{$\mathrm{H}^{\prime}$} & Exponential & 2000 & 0.03 & 0.17 & 317.57 & 82 \\
\hline & & 2005 & 0.02 & 0.16 & 207.81 & 87 \\
\hline & & 2014 & 0.03 & 0.09 & 299.57 & 68 \\
\hline FDI & Spherical & 1999 & 0.3 & 2.01 & 117.85 & 87 \\
\hline
\end{tabular}

${ }^{1} \mathrm{Co}=$ Nugget effect $\mathrm{Co}+\mathrm{C}=\mathrm{Sill} ; \mathrm{A}=$ Range $\mathrm{SD}=$ Spatial dependence . 

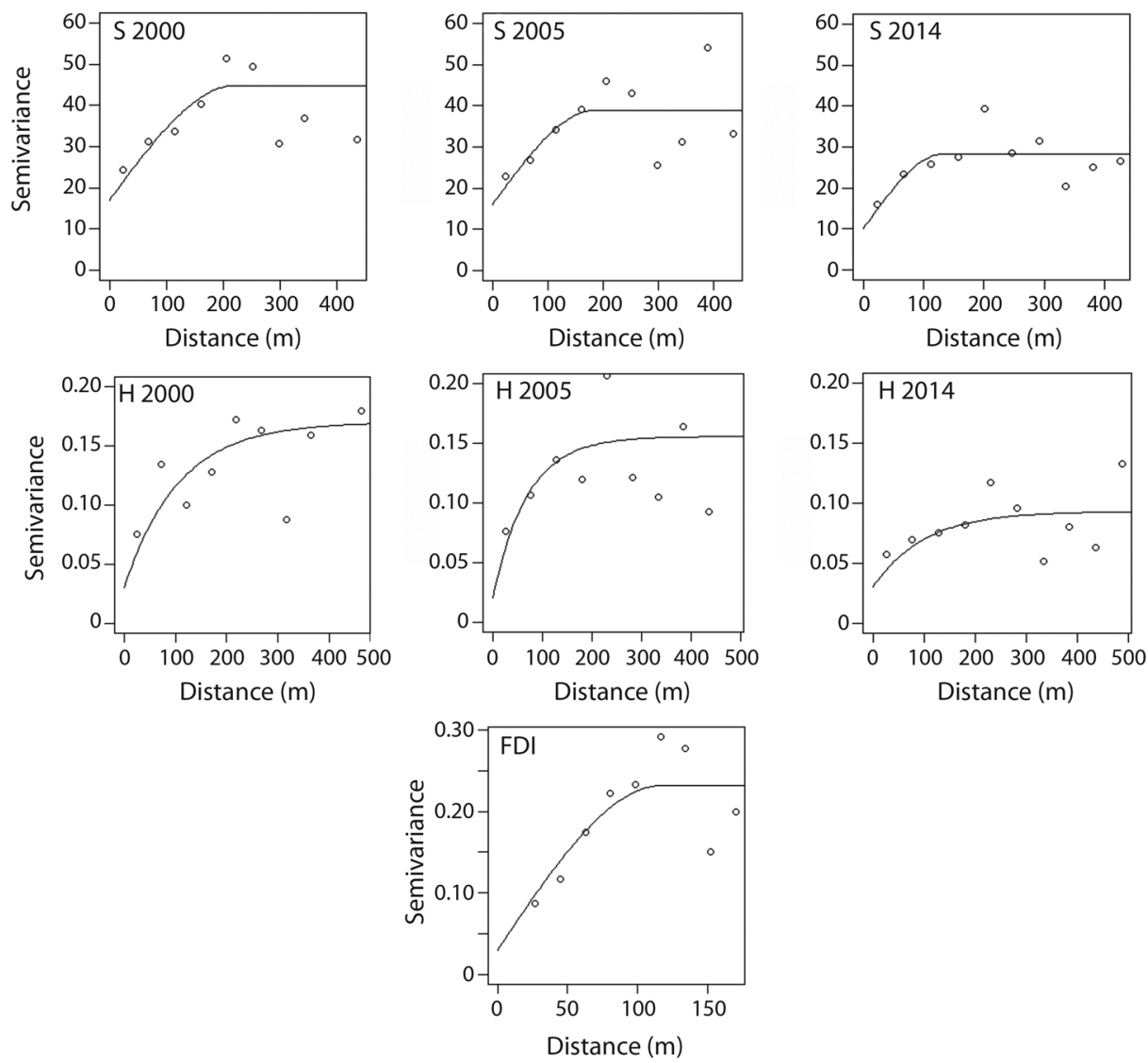

Fig. 2. Spherical and exponential semivariograms for the variables of species richness (S), Shannon diversity index ( $\left.H^{\prime}\right)$ and the Fire Damage Index (FDI) in a fragment of semideciduous seasonal forest in Ibituruna, MG, Brazil, during plant surveys undertaken in 2000, 2005 and 2014.

was stronger for the 2000 and 2005 surveys, and only moderate in 2014 (Table 2). Both variables demonstrated reductions in their value ranger, nugget effect, and sill during the series of three surveys (Table 2), that is, a reduction in the distance under spatial influence, and the uniformity of tree distributions in the forest fragment.

The variables FDI, S, and H' showed spatial dependence and aggregated patterns of distribution (Fig. 2 and Fig. 3). The fire spread from East to West and some fragment areas were more severely damaged (FDI) (Fig. $3)$; these focal points likewise demonstrated smaller $\mathrm{S}$ and $\mathrm{H}$ ' values and a gradient was established from them (Fig. 3). In these cases, the spatial distributions of the arboreal species were dependent on their distances from the focal points of the fire.

There was an increase in areas showing greater species richness and a reduction in areas with high species diversity following the first survey (Fig. 3).

\section{DISCUSSION}

It was not possible to characterize the influences of the fire on the structure of the arboreal community studied here, based on numerical analyses and the accumulation curves of $\mathrm{S}$ and $H^{\prime}$ variables. The $\mathrm{S}$ values in all three surveys were intermediate in relation to other seasonal 


\section{S 2000}

$w-\frac{1}{S}=$

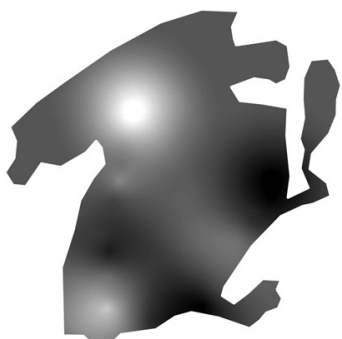

Species richness $(\mathrm{S})$

30.35
12.72

$H^{\prime} 2000$
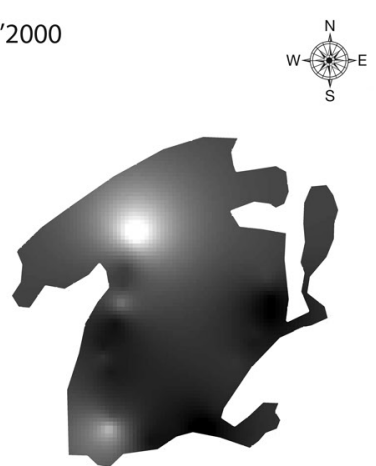

Shannon Diversity Index $\left(\mathrm{H}^{\prime}\right)$

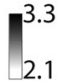

S 2005

$w-\underbrace{N}_{S}$

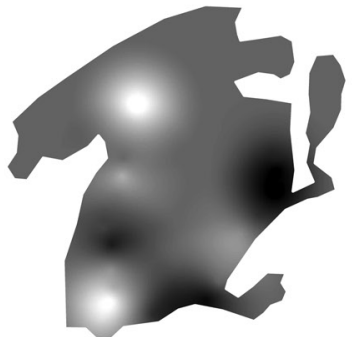

Species richness $(\mathrm{S})$

28.8
15.0

$H^{\prime} 2005$
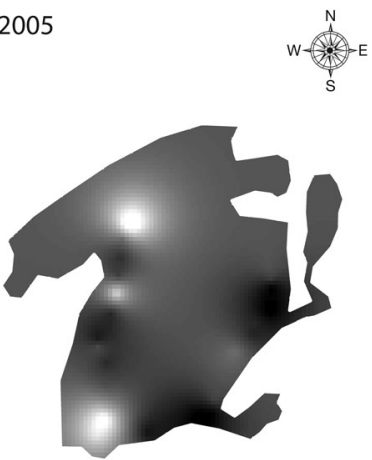

Shannon Diversity Iridex $\left(\mathrm{H}^{\prime}\right)$

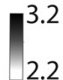

S 2014

$w-\frac{N}{S}$

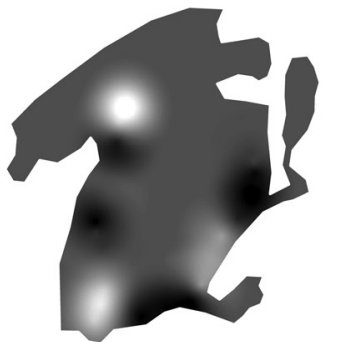

Species richness $(\mathrm{S})$

27.6
17.1

$H^{\prime} 2014$

$w-\frac{1}{S} E$

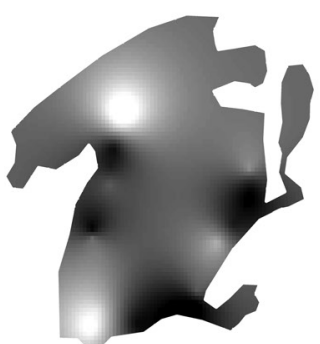

Shannon Diversity Index $\left(\mathrm{H}^{\prime}\right)$

$\mathbf{m}^{3.1}$

FDI

$w-\frac{1}{S}$

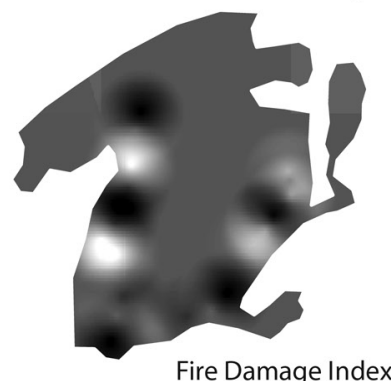

Fire Damage Index

$$
\begin{aligned}
& 3.9 \\
& 0.21
\end{aligned}
$$

Fig. 3. Kriging maps for the species richness (S), Shannon diversity index (H'), and Fire Damage Index (FDI) variables in a semideciduous seasonal forest fragment in Ibituruna, MG, Brazil, in three floristic surveys undertaken in 2000, 2005 and 2014 . 
semideciduous forest with known fire occurrences; Peixoto et al. (2012) reported from 148 to 168 species, while Abreu, Pinto and Mews (2014) reported from 102 to 100 species under similar conditions, and the latter group was unable to identify alterations in the forest community after a fire event (as was seen in the present study).

The H'values reported here were intermediate in terms of published results from other forest fragments for the same region (Alto Rio Grande) without reported fires (Botrel, Filho, Rodrigues, \& Curi, 2002; Nunes, Mendonça, Filho, Botezelli, \& Machado, 2003; Dalanesi, Filho, \& Fontes, 2004; Guilherme, Filho, Appolinário, \& Bearzoti, 2004; Carvalho, Filho, Fontes, \& Curi, 2007). As such, the numerical analyses of the H' variable was not useful to characterize the consequences of the event of fire or alterations resulting from regeneration processes, and could only be characterized based on the spatial analyses of the data.

The differential effects of fire in the sampled plots contributed to the observed variability of the data, although the reductions of the values of the coefficient of variation and the measures of dispersion ( $\mathrm{s}^{2}$ and $\mathrm{s}$ ), indicated the reestablishment of homogeneous distributions of S and H' after the disturbance.

Aggregated patterns of spatial distribution are characteristic results of fires in small forest fragments (Pereira, Barros, Acerbi-Junior, Pereira, \& Reis, 2013). After a fire event, areas (or foci) are created with smaller $\mathrm{S}$ and $\mathrm{H}^{\prime}$ values due to high fire damage intensity in those sites, resulting in spatial distribution gradients of the variables analyzed, which are dependent on their distance from those foci. As disturbances of equivalent proportions are not repeated, this interference gradually becomes reduced, characterizing natural regeneration. This result could also be seen in the attenuation of spatial dependence in sequential surveys. In terms of the variable H', the spatial dependence was classified as strong in 2000 , but alternated to moderate in 2014; this demonstrated a lower degree of dependence in relation to the initial foci.
The occurrence of clearings in forest fragments can initially result in independence of the different regions of the forest community (Lima, 2005; Lima \& Moura, 2006), with consequent spatial dependence on the pre-existing population. These canopy opening sites are initially colonized by species that had been excluded by interspecific competition, but returned and became established in those recently disturbed sites (Fox, 2013). This was observed in the present study, with a reduction in the areas that demonstrated small $\mathrm{S}$ values in the 2000 survey, with distancing occurring between new individuals and their mother plants during the process of natural regeneration, with consequent reductions in spatial dependence. After forest reconstruction, the renewed dominance of species adapted to lowlight environments resulted in reduced diversity (Bello et al., 2013).

Natural phenomena, in the case of natural regeneration, introduce spatial conditioning (Amaral et al., 2013a). As such, variations in plant distributions are not random and will demonstrate some degree of spatial dependence, and this dependence cannot be identified through classical analyses (Miller et al., 2007; Batista et al., 2016) as observed in the present study. In that sense, as described by Amaral et al. (2013a), analyses that assume independence among samples, have been substituted by geostatistical analyses that provide more reliable and precise data for decisionmaking by forest administrators.

As such, we were able to identify alterations in the configuration of the arboreal community after a fire disturbance by its influence on the spatial and temporal structures of the variables $\mathrm{S}$ and $\mathrm{H}$ '. These variables demonstrated spatial dependence and aggregated distributions, with reduction in the distance under spatial influences during the evaluation period, characterizing the stability of the arboreal community. During the process of natural regeneration, the distributions of these variables remained aggregated, although the more advanced successional stage demonstrated lower spatial dependence. 


\section{ACKNOWLEDGMENTS}

The authors would like to thank the team at the Laboratório de Silvicultura e Ecologia of the Departamento de Engenharia Florestal of the Universidade Federal de Lavras (UFLA) for their assistance with the fieldwork. K. G. Silva thanks the Coordenação de Aperfeiçoamento de Pessoal de Nível Superior (CAPES) for the doctoral scholarship grant.

\section{RESUMEN}

Distribución espacial y temporal de la diversidad de especies en un bosque estacional semideciduo con un episodio de incendio. La distribución espacial y temporal de la vegetación esta influenciada por factores edáficos, ambientales y alteraciones. En ese contexto, el objetivo del estudio fue caracterizar el patrón de distribución y la dependencia espacial de la diversidad de especies en un fragmento de bosque estacional semideciduo, donde ocurrió un incendio, e identificar alteraciones a lo largo del proceso de regeneración natural. El incendio ocurrió en 1999, y en 2000, 2005 y 2014, se hicieron inventarios florísticos en 26 parcelas $\left(400 \mathrm{~m}^{2}\right)$ georreferenciadas y distribuidas en dos transectos. El índice de daño del fuego (IDF) se evaluó en cada parcela con base en una escala de 0 a 5. En cada inventario se identificaron las plantas arbóreas con diámetro a altura de pecho (DAP) $\geq 5 \mathrm{~cm}$, calculando la diversidad de especies con base en el índice de Shannon $\left(H^{\prime}\right)$ y estimando la riqueza de especies (S). Esas variaciones fueron analizadas utilizando la curva de acumulación de especies, y la variación entre inventarios fue comparada con base en las medias y el error estándar. Los datos de $\mathrm{S}, \mathrm{H}^{\prime}$ e IDF fueron sometidos a análisis exploratorio no espacial y a análisis geoestadístico. Después del ajuste de los semivariogramas, se clasificó el nivel de dependencia espacial y se hizo la interpolación de datos por Krigeado ordinario para caracterizar, en mapas, el patrón de distribución espacial de esas variables. Se encontró diferencia entre los inventarios realizados después del incendio, como en la configuración de la comunidad arbórea, por lo que el análisis espacial permitió identificar y caracterizar este hecho. El incendio afectó la estructura espacial y temporal de las variables $\mathrm{S}$ y H'. Estas variables presentan dependencia espacial y la distribución agregada, con distancias más pequeñas bajo influencia espacial, y la uniformidad de la distribución de los individuos en el fragmento de bosque durante las distintas etapas. Por último, se caracterizó la distribución y la dependencia espacial de las variables $\mathrm{S}$ e $\mathrm{H}$ 'en un fragmento de bosque después de un incendio, $\mathrm{y}$ las alteraciones en la estructura de la comunidad arbórea durante la regeneración natural.
Palabras clave: Selva Atlántica, Brasil, fragmentación de bosques, alteración antropógena, estudio a largo plazo, dependencia espacial, geoestadística.

\section{REFERENCES}

Abreu, T. A. L., Pinto, J. R. R., \& Mews, H. A. (2014). Variações na riqueza e na diversidade de espécies arbustivas e arbóreas no período de 14 anos em uma Floresta de Vale, Mato Grosso, Brasil. Rodriguésia, $65,73-88$.

Amaral, L. P., Ferreira, R. A., Lisboa, G. S., Longhi, S. J., \& Watzlawick, L. F.(2013a). Variabilidade espacial do Índice de Diversidade de Shannon-Wiener em Floresta Ombrófila Mista. Scientia Forestalis, 41, 83-93.

Amaral, L. P., Ferreira, R. A., Watzlawick, L. F., \& Genú, A. M. (2010). Análise da distribuição espacial de biomassa e carbono arbóreo acima do solo em Floresta Ombrófila Mista. Revista Ambiência, 6, 103-114.

Amaral, L. P., Ferreira, R. A., Watzlawick, L. F., Longhi, S. J., \& Sebem, E. (2013b). Influência da floresta alterada na distribuição espacial de três espécies da Floresta Ombrófila Mista avaliada pela geoestatística. Revista Árvore, 37, 491-501. doi: org/10.1590/ S0100-67622013000300012

Batista, A. P. B., Mello, J. M., Raimundo, M. R., Scolforo, H. F., Reis, A. A., \& Scolforo, J. R. S. (2016). Species richness and diversity of a Shrub savanna using ordinary kriging. Pesquisa Agropecuária Brasileira, 51, 958-966. doi: 10.1590/S0100-204X2016000800008

Bello, F., Vandewalle, M., Reitalu, T., Leps, J., Prentice, H. C., Lavorel, S., \& Sykes, M. T. (2013). Evidence for scale- and disturbance-dependent trait assembly patterns in dry semi-natural grasslands. Journal of Ecology, 101, 1237-1244. doi: 10.1111/1365-2745.12139

Biondi, F., Myers, D. E., \& Avery, C. C. (1994). Geostatistically modeling stem size and increment in an oldgrowth forest. Canadian Journal of Forest Research, 24, 1354-1368. doi: 1354-1368, 10.1139/x94-176

Botrel, R. T., Filho, A. T. O., Rodrigues, L. A., \& Curi, N. (2002). Influência do solo e topografia sobre as variações da composição florística e estrutura da comunidade arbóreo-arbustiva de uma floresta estacional semidecidual em Ingaí, MG. Revista Brasileira de Botânica, 25, 195-213.

Carvalho, W. A. C., Filho, A. T. O., Fontes, M. A. L., \& Curi, N. (2007). Variação espacial da estrutura da comunidade arbórea de um fragmento de floresta semidecídua em Piedade do Rio Grande, MG, Brasil. Revista Brasileira de Botânica, 30, 315-335.

Colwell, R. K. (2013). EstimateS version 9.1: Statistical estimation of species richness and shared species 
from samples. Storrs: University of Connecticut, United States American.

Condit, R., Ashton, P., Baker, P., Bunyavejchewin, S., Gunatilleke, S., Gunatilleke, N., ... Yamakura, T. (2000). Spatial patterns in the distribution of tropical tree species. Science, 288, 1414-1418. doi: 10.1126/ science.288.5470.1414

Dalanesi, P. E., Filho, A. T. O., \& Fontes, M. A. L. (2004). Flora e estrutura do componente arbóreo da floresta do Parque Ecológico Quedas do Rio Bonito, Lavras - MG, e correlações entre a distribuição das espécies e variáveis ambientais. Acta Botânica Brasílica, 18, 737-757. doi.org/10.1590/ S0102-33062004000400005

Dantas, A. A. A., Carvalho, L. G., \& Ferreira, E. (2007). Classificação e tendências climáticas em Lavras, MG. Ciência e Agrotecnologia, 31(6), 1862-1866.

Diggle, P. J., \& Ribeiro-Junior, P. J. (2007). Model-based geostatistics. New York: Springer.

Dormann, C. F. (2007). Effects of incorporating spatial autocorrelation into the analysis of species distribuition data. Global Ecology and Biogeography, 16, 129-138. doi: 10.1111/j.1466-8238.2006.00279.x

Empresa Brasileira de Pesquisa Agropecuária. (2006). Sistema Brasileiro de Classificação de Solos. Rio de Janeiro, Brasil: Empresa Brasileira de Pesquisa Agropecuária. Retrieved from http://www.embrapa.br/

Environmental Systems Research Institute (2010). ArcGIS Desktop: Release version 10.1. Redlands, California. Retrieved from: http://www.esri.com/

Fox, J. W. (2013). The intermediate disturbance hypothesis should be abandoned. Trends in Ecology \& Evolution, 28, 86-92. doi: 10.1016/j.tree.2012.08.014

Guilherme, F. A. G., Filho, A. T. O., Appolinário, V., \& Bearzoti, E. (2004). Effects of flooding regimes and woody bamboos on tree community dynamics in a section of tropical semideciduous forest in SouthEastern Brazil. Plant Ecology, 174, 19-36.

Instituto Brasileiro de Geografia e Estatística (2012). Manual técnico da vegetação brasileira. Rio de janeiro, Brasil: Instituto Brasileiro de Geografia e Estatística. Retrieved from: http://www.ibge.gov.br/

Journel, A. G., \& Huijbregts, C. J. (1978). Mining geostatistics. London: Academic.

Legendre, P., \& Fortin, M. J. (1989). Spatial pattern and ecological analysis. Vegetatio, 80, 107-38.

Lima, R. A. F. (2005). Estrutura e regeneração de clareiras em florestas pluviais tropicais. Revista Brasileira de Botânica, 28, 651-670.
Lima, R. A. F., \& Moura, L. C. (2006). Canopy gap colonization in the Atlantic Montane Rain Forest. Brazilian Archives of Biology and Technology, 49, 953-965. doi: org/10.1590/S1516-89132006000700013

Lima, R. A. F., \& Moura, L. C. (2008). Gap disturbance regime and composition in the Atlantic Montane Rain Forest: the influence of topography. Plant Ecology, 197, 239-253. doi: 10.1007/s11258-007-9374-x

Magurran, A. E. (1988). Ecological diversity and its measurements. Princeton: Princeton University.

Miller, J., Franklin, J., \& Aspinall, R. (2007). Incorporating spatial dependence in predictive vegetation models. Ecological Modelling, 202, 225-242. doi: 10.1016/j. ecolmodel.2006.12.012

Nascimento, M. T., Felfili, J. M., Filho, A. T. O., Fontes, M. A. L., França, J. T., Hay, J. D., \& Gribel, R. (2000). Efeitos do fogo nas florestas - as queimadas em Roraima. Ciência Hoje, 27, 40-43.

Neves, D. A., Lemos, F., Gonzáles, A. P., Vieira, S. R., \& Siqueira, G. M. (2010). Using geostatistics for assessing biodiversity of forest reserve areas. Bragantia, 69, 131-140.

Nunes, Y. R. F., Mendonça, A.V. R., Filho, A. T. O., Botezelli, L., \& Machado, E. L. M. (2003). Variações da fisionomia, diversidade e composição de guildas da comunidade arbórea em um fragmento de floresta semidecidual em Lavras, MG. Acta Botânica Brasílica, 17, 213-229. doi: org/10.1590/ S0102-33062003000200005

Peixoto, K. S., Sanchez, M., Pedroni, F., Ribeiro, M. N., Facure, K. G., Gomes-Klein, V. L., \& Guilherme, F. A. G. (2012). Dinâmica da comunidade arbórea em uma floresta estacional semidecidual sob queimadas recorrentes. Acta Botânica Brasílica, 26, 697-708. doi: org/10.1590/S0102-33062012000300020

Pereira, A. A., Barros, D. A., Acerbi-Junior, F.W., Pereira, J. A. A., \& Reis, A. A. (2013). Análise da distribuição espacial de queimadas através da função de $\mathrm{K}$ de Ripley. Scientia Florestalis, 41, 445-455.

Pereira, J. A. A., Filho, A. T. O., Eisenlohr, P. V., Miranda, P. L. S., \& Filho, J. P. L. (2015). Human Impacts Affect Tree Community Features of 20 Forest Fragments of a Vanishing Neotropical Hotspot. Environmental Management, 55, 296-307. doi: 10.1007/ s00267-014-0387-7

Pereira, A. A., Péllico-Netto, S., \& Carvalho, L. M. T. (2006). Análise da distribuição espacial de Jequitibá Rosa em uma Floresta Estacional Submontana. Revista Acadêmica, 4, 21-34.

R Development Core Team. (2012). R: A language and environment for statistical computing. R Foundation 
for Statistical Computing, Vienna, Austria. Retrieved from http://www.R-project.org/

Ribeiro, M. C., Martensen, A. C., Metzer, J. P., Tabarelli, M., Scarano, F., \& Fortin, M. J. (2011). The Brazilian Atlantic Forest: a shrinking biodiversity hotspot. In F. E. Zachos, \& J. C. Habel (Eds), Biodiversity hotspots: distribution and protection of conservation priority areas (pp. 405-434). Heidelberg: Springer.

Rode, R., Filho, A. F., Machado, S. A., \& Galvão, F. (2010). Análise do padrão espacial de espécies e de grupos florísticos estabelecidos em um povoamento de Araucaria angustifolia e em uma Floresta Ombrófila Mista no Centro-sul do Paraná. Floresta, 40, 255 268. doi: org/10.5380/rf.v40i2.17821

Rufino, T. M. C., Thiersch, C. R., Ferreira, S. O., Kanegae Junior, H., \& Fais, D. (2006). Uso da geoestatística no estudo da relação entre variáveis dendrométricas de povoamentos de Eucalyptus sp. e atributos do solo. Revista Ambiência, 2, 83-93.

Sanquetta, C. R., Corte, A. P. D., Salzmann, A. M., \& Vulcanis, L. (2007). Dinâmica de um remanescente de Floresta Ombrófila Mista no sul do Paraná sob influência de taquaras. Revista Ambiência, 3, 65-78.

Silva, V. F., Filho, A. T. O., Venturin, N., Carvalho, W. A. C., \& Gomes, J. B. V. (2005). Impacto do fogo no componente arbóreo de uma floresta estacional semidecídua no município de Ibituruna, MG, Brasil. Acta Botanica Brasilica, 19, 701-716. doi: org/10.1590/ S0102-33062005000400005

Silva-Matos, D. M., Fonseca, G. D. F. M., \& Silva-Lima, L. (2005). Differences on post-fire regeneration of the pioneers Cecropia glazioui and Trema micrantha in a lowland Brazilian Atlantic Forest. Revista de Biología Tropical, 53, 1-4.

Taylor, D., Hamilton, A. C., Lewis, S. L., \& Nantale, G. (2008). Thirty-eight years of change in a tropical Forest: plot data from Mpanga Forest Reserve, Uganda. African Journal of Ecology, 46, 655-667. doi: 10.1111/j.1365-2028.2008.00955.x

Zar, J. H. (2010). Biostatistical analysis (5 ed). Upper Saddle River, New Jersey: Prentice-Hall. 